\title{
Menegakkan Kembali Perilaku Gotong - Royong Sebagai Katarsis Jati Diri Bangsa
}

\author{
Kukuh Setyo Pambudi', Dwi Sri Utami²
}

\author{
${ }^{1}$ Damai dan Resolusi Konflik, Universitas Pertahanan, kukuhpambudi@ymail.com \\ ${ }^{2}$ Fakultas Pendidikan Psikologi, Universitas Negeri Malang, dwiutami1403@gmail.com
}

INFO ARTIKEL
Riwayat Artikel:
Diterima: 08 September
2020
Disetujui: 30 September
2020

Kata Kunci:

Perilaku

Gotong-royong

Jati-diri bangsa

Pendidikan karakter

\begin{abstract}
ABSTRAK
Abstrak: Penelitian ini bertujuan untuk mendeskripsikan perilaku gotong-royong sebagai katarsis jati diri bangsa yang tengah banyak ditinggalkan. Metode penelitian yang dipakai adalah kualitatif deskriptif dengan kajian pustaka sebagai tulang punggung utama pengumpulan data. Saat ini identitas Budaya Kolektif dari bangsa Indonesia mulai luntur. Tren meninggalkan budaya kolektif juga semakin kuat jika melihat tren masyarakat yang mulai abai dengan kepentingan Umum dan lebih mementingkan kepentingan pribadi. Oleh karena itu mengembalikan masyarakat pada Jati Diri dan nilai bangsanya menjadi sangat krusial. Perilaku gotong - royong yang pada jaman dahulu menjadi roh budaya kolektif agaknya dapat ditegakkan lagi. Perilaku gotong - royong merupakan perilaku saling membantu, bentuk solidaritas dan sinergi antar masyarakat. Perilaku ini dapat menjadi strategi meningkatkan kembali nilai - nilai. Kolektivitas yang mulai luntur. Menegakkan kembali perilaku gotong - royong yang pernah menjadi ruh pemersatu bangsa yang dulu pernah ada, akan dapat menjadi katarsis untuk mengembalikan budaya bangsa. Oleh karena itu nilai - nilai dan perilaku gotong royong harus ditegakkan kembali guna mengembalikan Jati Diri Bangsa Indonesia ke arah yang seharusnya.
\end{abstract}

\begin{abstract}
This study aims to describe the behaviour of cooperation as a catharsis of national identity that is being largely abandoned. The research method used is descriptive qualitative with literature review as the main backbone of data collection. Currently, the collective cultural identity of the Indonesian nation is starting to fade. The trend of leaving a collaborative culture is also getting more assertive if you look at the trend in society that is beginning to ignore the public interest and prioritize personal interests. Therefore, returning society to the identity of its nation and the value of its people is very crucial. It seems that the cooperation behaviour, which in ancient times became the spirit of a collective culture, can be reinforced. Cooperation behaviour is the behaviour of mutual help, a form of solidarity and synergy between communities. This behaviour can be a strategy to increase the collectivity values that are starting to wear off. Re-enforcing the cooperation behaviour that was once the unifying spirit of the nation that once existed, will be a catharsis to restore the nation's culture. Therefore, the values and behaviour of cooperation must be re-enforced to return the Indonesian National Identity to the direction it should be.
\end{abstract}

\section{A. LATAR BELAKANG}

Indonesia saat ini merupakan salah negara dengan jumlah penduduk dengan jumlah terbanyak. Pada sensus penduduk tahun 2010 indonesia mempunyai jumlah penduduk sebanyak 249,9 juta jiwa (bps.go.id). Jumlah yang sangat besar, namun memiliki kerentanan terhadap terjadinya konflik. Kerentanan terjadinya konflik adalah akibat dari latar belakang dan keberagaman yang sangat luas di wilayah Indonesia. Terdapat lebih dari tujuh belas ribu pulau yang tersebar di seluruh wilayah Indonesia, yang didalamnya terdapat perbedaan bahasa, suku, ras, agama, dan budaya. Keberagaman tersebut apabila dapat dikelola dengan baik akan membuat suatu harmonisasi yang indah.
Namun sebaliknya, akan menjadi potensi konflik yang sangat luas apabila tidak dikelola dengan baik.

Besarnya jumlah penduduk tersebut dengan keberagaman dan potensi konflik saat ini juga tengah mengalami permasalahan pelik yakni tergerusnya budaya kolektif yang telah membangun bangsa Indonesia sejak pertama kali lahir. saat ini nilai - nilai ke Indonesiaan kerap diabaikan oleh masyarakat Indonesia. Budaya materialisme dan modernisme telah menguasai sendi - sendi kehidupan bangsa Indonesia cukup menjadi penyebab runtuhnya nilai - nilai ke Indonesiaan[1]. Budaya - budaya baru tersebut merongrong dan terus masuk serta diterima dengan baik oleh masyarakat yang tengah gegap gempita dengan era globalisasi. 
Tersisih dan hilang, mungkin itulah yang berkemungkinan terjadi pada jati diri bangsa Indonesia yang tengah gemar meningalkan nilai - nilai bangsanya. Tantangan jaman dan era globalisasi yang tak bisa terbendung akan terus membuat nilai dan perilaku sesuai dengan jati diri bangsa Indonesia tersisih dan hilang. Selanjutnya menjadi tantangan bagi semua kalangan untuk mengembalikan dan mensucikan kembali jati diri Bangsa Indonesia. Dengan demikian langkah untuk mengembalikan bangsa Indonesia pada jati dirinya mutlak diperlukan.

Sebagai negara dengan jumlah penduduk yang sangat banyak, menjadikan Indonesia memiliki budaya yang kolektif. Sebagai contoh dalam budaya Jawa seperti yang tercantum dalam buku Abangan, Santri, dan Priyai karya Clifford Geertz banyak dikisahkan tentang kebiasaan kolektif seperti slametan. Slametan menurut Geertz[2] merupakan upacara keagamaan yang paling umum di dunia; melambangkan kesatuan mistis dan sosial mereka yang ikut serta didalamnya. Prosesi seperti itu menjadi bukti bahwa budaya kolektif telah mengakar dalam diri Bangsa Indonesia, meskipun beberapa tahun belakangan ini tengah mengalami penurunan. Selain ada pada budaya jawa, dalam budaya lain di Indonesia pun dapat dengan mudah ditemukan hal serupa. Demikian juga dengan falsafah Indonesia yakni Pancasila, didalamnya juga terdapat contoh dari lekatnya budaya kolektif di Indonesia. Pada masyarakat Indonesia, dapat ditemukan nilai sosial budaya yang selama ini menjadi karakter atau kepribadian kolektif bangsa[3].

Jati diri Bangsa Indonesia yang terbentuk dari budaya koletif itulah yang perlu untuk segera mungkin dikembalikan ke arah yang seharusnya. Menegakkan kembali perilaku gotong - royong agaknya dapat menjadi langkah untuk mengembalikan jati diri bangsa. Perilaku gotong - royong bukanlah hal baru, perilaku ini merupakan buah dari budaya kolektif itu sendiri. Pada masyarakat Indonesia, dapat ditemukan nilai sosial budaya yang selama ini menjadi karakter atau kepribadian kolektif bangsa[3]. Gotong - royong merupakan salah satu diantara banya nilai sosial budaya bangsa tersebut.

Gotong - royong merupakan perekat antar masyarakat ditengah perbedaan dan gempuran perubahan peradaban. Eksistensi perilaku gotong royong telah ada sejak lama dan telah menjadi salah satu warisan budaya yang berusaha untuk dilestarikan oleh para leluhur bangsa. Banyak tradisi, kepercayaan, dan upacara masyarakat di Indonesia secara langsung maupun tidak langsung mengarahkan masyarakatnya untuk hidup dalam harmoni. Seperti dikatakan oleh Subagyo[3] kehidupan harmoni masyarakat masyarakat Jawa, yang juga dimiliki oleh masyarakat suku bangsa lain di Indonesia salah satu terwujud dalam budaya yang disebut gotong royong. Oleh karena itu perilaku gotong royong dapat menjadi salah satu senjata ampuh untuk melawan terkikisnya jati diri bangsa yang semakin terlihat jelas.

\section{B. METODE PENELITIAN}

Penelitian ini mengunakan pendekatan penelitian kualitatif. Pendekatan jenis ini mengedepankan katakata dan tindakan sebagai objek kajian utama[4]. Pengunaan pendekatan kualitatif ditujukan untuk mengungkapkan lebih jauh dan memberikan satu analisis yang mendalam dalam mengungkap objek penelitian. Selain itu, objek penelitian yang dekat dengan identitas dan konsep budaya akan lebih baik dengan pengunaan kualitatif.

Sumber data dalam penelitian ini didapatkan dari kajian literatur. Sumber data primer adalah catatan, referensi, dan buku yang terkait dengan objek penelitian. Dalam tulisan ini digunakan beberapa buku yang menjadi sajian utama data penelitian, diantaranya adalah Religion of Java dan beberapa buku yang ditulis oleh Prof. M. Yamin.

\section{HASIL DAN PEMBAHASAN}

\section{Budaya Kolektif Sebagai Jati Diri Bangsa Indonesia}

Budaya Kolektif adalah budaya yang budaya yang menitik beratkan pada kepentingan kelompok dibandingkan dengan kepentingan pribadi. Dalam budaya kolektif pribadi individu kolektif termasuk pribadi yang saling tergantung atau sangat dipengaruhi oleh kelompoknya[2]. Dalam budaya ini akan sangat nampak sekali harmonisasi antar anggota kelompok dan kerja sama dalam berbagai hal didalamnya. Pada masyarakat Indonesia sangat mudah menemukan budaya kolektif, karena pada dasarnya masyarakat Indonesia adalah masyarakat yang dibentuk oleh budaya kolektif. Selama ini bangsa Indonesia yang hidup dalam keramahannya dan harmonisasi kehidupannya memang sudah sangat tersohor. Hal tersebut dapat dilihat dari aspek - aspek sosial budaya yang ada di Indonesia. Seperti pendapat Subagyo bahwa pada masyarakat Indonesia dapat ditemukan banyak nilai sosial budaya yang selama ini menjadi karakter atau kepribadian kolektif bangsa.[3] Konsep yang paling banyak dibahas oleh Geertz dalam buku terkenalnya The Religion of Java pun banya menerangkan tentang konsep selametan yang tak lain adalah salah satu konsep bentukan budaya kolektif.

Oleh karena itu penulis pada tulisan ini akan mengangkat jati diri bangsa khususnya sebagai bangsa dengan budaya kolektif. Hal tersebut dikarenakan budaya kolektif adalah budaya yang tertanam di Indonesia dengan beragam terjemahan dalam setiap budaya dan suku di Indonesia. Selain itu budaya kolektif saat ini juga tengah terkikis, sehingga diperlukan langkah - langkah untuk mengembalikan jati diri bangsa khususnya budaya kolektif. 


\section{1) Perilaku Gotong Royong}

Secara konseptual gotong royong dapat diartikan sebagai suatu model kerjasama yang disepakati bersama. Nilai gotong royong adalah semangat yang diwujudkan dalam bentuk perilaku atau tindakan indvidu yang dilakukan tanpa pamrih. Koentjaraningrat membagi dua jenis gotong royong yaitu gotong royong tolong menolong dan gotong royong kerja bakti. Kegiatan gotong royong terjadi pada aktivitas pertanian, kegiatan seputar rumah tangga, pesta, perayaan ataupun peristiwa bencana dan kematian.[5][6] Sedangkan gotong royong kerja bakti lebih sering dilakukan untuk mengerjakan sesuatu hal yang sifatnya umum.

Secara Etimologis Gotong Royong merupakan istilah dalam Bahasa Jawa. Kata Gotong berasal dari gotong atau orang Jawa biasanya mengatakan dengan "nggotong" yang artinya memikul. Sedangkan kata Royong terinspirasi dari pohon yang ada di alun-alun keraton jogja yang artinya bisa dimakna dengan bersama-sama.

Kata gotong royong telah digunakan oleh semua lapisan masyarakat, dari kalangan birokrat dan pemimpin pemerintahan sampai kalangan buruh tani, tukang ojek, sampai dengan peronda malam di kampung-kampung. Beberapa daerah memaknai gotong royong sebagai istilah lain.

Dalam sejarah Indonesia, konsep Gotong - royong telah lama dipakai. Kobayashi[7] menyebutkan pada masa orde baru pimpinan Soeharto mengunakan tradisi gotong - royong sebagai sebuah penanaman "moral fact" untuk menciptakan pembangunan dan stabilitas negara. Sementara itu pada era Presiden Soekarno konsep gotong royong diterapkan dengan pengertian memberikan kebersamaan antara umat muslim dan kristen, kaya dan miskin, orang asli Indonesia dan pendatang dalam sebuah sebuah kesatuan yang toleran demi mengalang kekuatan untuk melawan musuh, imperialisme, dan kapitalisme, dan kekuatan lain yang berniat untuk menjadi musuh dan memecah belah kesatuan bangsa.

Eksistensi gotong - royong memang sudah ada sejak lama dan menjadi perekat kohesivitas antar masyarakat. Sehingga kemudian untuk memunculkan kembali perilaku gotong royong sebagai sebuah langkah untuk memeranggi pengikisan jati diri bangsa adalah perlu. Perilaku gotong royong selanjutnya menjadi sangat mungkin dilakukan dan sangat diperlukan.

2) Perilaku Gotong Royong Berdasarkan

Sosiolinguistik

Language is a vital element of culture[8].[9] Bahasa merupakan salah satu unsur pembentuk budaya, tiada budaya tanpa bahasa. Bahasa mengekspresikan keadaan lokal, regional, maupun nasional. Kata gotong royong disebut dengan kata yang berbeda antara satu daerah ke daerah yang lain. Di Bali dikenal istilah "Subak", merupakan salah satu bentuk gotong royong dalam sistem pengairan di daerah tersebut.

Terdapat istilah "mapalus" sinonim gotong royong yang berasal dari Minahasa Sulawesi Utara. Di Aceh istilah gotong royong diwujudkan ke dalam tradisi khanduri, yaitu satu ritual yang bertujuan untuk memohon berkah, keselamatan atau mengucap rasa syukur kepada Tuhan. Meski dari antara satu daerah dengan yang lain berbeda istilah, akan tetapi nilai gotong royong yang terkandung dalam masing-masing daerah sama.

Kesamaan arti menjadikan konsep gotong - royong tetap tertanam meskipun dalam pelafalan di tiap daerah berbeda - beda. Sebagai suatu konsep yang utuh konsep tentang gotong - royong yang di ekspresikan oleh masyarakat di berbagai daerah tetaplah mengajarkan hal yang sama. Pengajaran tentang perilaku gotong royong tersebut dimaksutkan untuk ditanamkan dengan ekspresi dan istilah yang berbeda - beda berdasarkan budaya yang ada di tiap - tiap sudut Nusantara.

\section{Perilaku Gotong - Royong Sebagai Kearifan Lokal}

Kearifan lokal atau local wisdom merupakan kekayaan budaya masyarakat suku-suu bangsa yang memiliki potensi sebagai pembentuk karakter bangsa. Maka gotong royong merupakan salah satu nilai kearifan lokal masyarakat Indonesia, yang artinya gotong royong telah menjadi ciri khas bangsa Indonesia yang membedakannya dengan bangsa lain (common identity), gotong royong merupakan karakter bangsa Indonesia yang nilai-nilainya telah lama diwariskan oleh leluhur sehingga melekat dalam jiwa dan kepribadian bangsa, serta gotong royong menjadi alternatif bangsa untuk menyelesaikan berbagai problema yang melanda dalam seluruh aspek kehidupan berbangsa dan bernegara. Tujuan dari terciptanya gotong royong adalah untuk membangun solidaritas antar bangsa, menyatukan yang berbeda dan mempererat hubungan sosial dengan cara melakukan kerja sama secara bersama-sama.

Gotong royong dapat dijadikan salah satu model pembelajaran yang berbasis culture of peace education yang khas berasal dari Indonesia. Dengan adanya gotong royong, kedamaian, harmonisasi sosial, rasa kekeluargaan serta rasa nyaman terhadap lingkungan sosial dapat tercipta. Setiap orang ataupun orang lain memiliki tanggung jawab bersama untuk saling membangun serta menjaga kohesi dalam kerjasama.

Eksistensi Gotong Royong, Gotong royong merupakan tradisi yang turun temurun diwariskan dari generasi nenek moyang sampai generasi saat ini. Tentunya eksistensi gotong royong tidak selalu berada pada titik stabil. Seiring berjalannya waktu perubahan pasti terjadi. Sepuluh tahun yang lalu mungkin sering terlihat kegiatan-kegiatan kerja bakti di kampung, kegiatan membangun masjid yang dilakukan oleh orang desa 
ataupun memperbaiki jembatan yang roboh dilakukan secara bersama-sama oleh warga.[10][11][12]

Perubahan negara ke arah industrialisasi membuat kegitan gotong royong meredup. Sebagian besar lebih memilih untuk mendonasikan uang daripada tenaga. Kesibukan bekerja yang tinggi membuat seseorang enggan untuk mau berkontribusi dalam gotong royong. Seringkali ketika diajak kerja bakti, seseorang akan mengungkapkan berbagai alasan untuk tidak mengikutinya.

Masyarakat saat ini cenderung lebih matrealistis daripada menjadi sukarelawan. Mereka tidak mau membantu apabila tidak ada upah atau manfaat pribadi yang nanti didapat olehnya. Industrialisasi serta matrealisme, dua hal inilah yang mempengaruhi eksistensi gotong royong menjadi meredup. Hasil penelitian Suprihatin (8) menemukan bahwa Setelah pertambangan batubara hadir dan beroperasi di Desa Mulawarman, perilaku masyarakat dalam bergotong royong lebih berorientasi pada materi atau sistem bayaran (upah). Intensitas partisipasi masyarakat dalam kegiatan gotong royong pun mengalami penurunan karena faktor kesibukan dalam pekerjaan masingmasing warga yang kian bervariasi.

\section{APLIKASI PERILAKU GOTONG ROYONG DALAM MASYARAKAT}

Dalam kehidupan masyarakat perilaku gotong royong dapat di aplikasikan dalam berbagai kegiatan. Kegiatan-kegiatan tersebut akan dikelompokkan menjadi beberapa bagian, sebagai berikut :

\section{Kegiatan pertanian}

Mekanisme penggarapan lahan seperti pada saat buka lahan yang berupa babat rumput, bikin galengan, bajak sawah kemudian nanam padi dan matun (bersihkan rumput disela-sela tanaman padi) dikerjakan oleh masyarakat dengan menggunakan sistem kelompok secara bergantian. Yang mana kelompok tersebut dibentuk secara kondisional berdasarkan kesepakatan dan bukan kelompok formal yang terstruktur.

\section{Kegiatan Amal,}

Sistem gotong royong dapat dimanfaatkan untuk kegiatan amal. Menarik perhatian seseorang untuk peka terhadap suatu permasalahan yang dialami oleh orang lain. Di jaman modern saat ini, kegiatan amal mudah dijangkau dan dipromosikan melalui media sosial, salah satu contohnya ialah koin untuk Prita, masker untuk bencana asap yang terjadi di beberapa tempat di Indonesia dan masih banyak lagi bentuk kegiatan amal lainnya.

\section{Permainan Tradisional,}

Gobhag sodor adalah salah satu permainan tradisional yang menerapkan sistem gotong royong antar anggota kelompok. Selain gobhag sodor, masih ada permainan yang membutuhkan gotong royong yang sering dimainkan dalam acara kemerdekaan seperti tarik tambang, balapan bangkiak, panjat pinang dan lain-lain.
4. Kegiatan Penanganan Bencana/Musibah

Tolong menolong dalam mengatasi musibah merupakan sikap kepedulian masyarakat untuk saling membantu sesamanya seperti pada musibah kematian, sakit, kecelakaan maupun yang menjadi korban bencana alam. Seperti pada bencana gempa bumi yang terjadi di Jogjakarta pada 2006 silam, penelitian yang dilakukan oleh Mardiasmo \& Barnes [7] menemukan bahwa konsep gotong - royong sangat berperan dalam penanganan pasca gempa yang terjadi tersebut.

\section{Kegiatan pada bidang rumah tangga}

Seperti pada acara pernikahan, khitanan, dan aqikahan gotong royong sangat dibutuhkan untuk memperlancar jalannya acara dan memperingan beban kerja selama

6. Kegiatan pada bidang kepentingan umum

Gotong royong pada bidang kepentingan umum yaitu aktivitas kerja bakti pada kegiatan yang menyangkut kepentingan bersama seperti memperbaiki jalan, jembatan, parit dan renovasi tempat ibadah.

\section{Kegiatan Keamanan}

Terdapat istilah siskamling, dimana sekelompok tetangga akan berjaga-jaga di kompleks perumahan saat malam hari demi melindungi para tetangga lainnya dari bahaya. Konsep siskamling ini sering kali mengalami pasang surut, meski keberadaannya sangat bermanfaat bagi keberlangsungan keamanan di wilayah.

\section{TEMUAN ATAU DISKUSI}

Mengembalikan kembali identitas diri bangsa sebagai bangsa dengan budaya kolektif yang kuat tidaklah mudah. Diperlukan keterlibatan dan dukungan dari semua pihak. Keterlibatan dan dukungan semua pihak diperlukan karena mengembalikan jati diri bangsa mencakup hal yang sangat luas dan beragam. Beberapa hal yang dapat menjadi kontributor dalam melakukan pengembalian jati diri bangsa diantaranya :

\section{Diri sendiri}

Dengan meningkatkan kesadaran akan persatuan dan kesatuan dengan implikasi dari nilai-nilai pancasila dalam kehidupan sehari-hari terutama sila ketiga, Persatuan Indonesia. Selain itu dengan menanamkan rasa cinta kasih kepada sesama dan mementingkan kepintingan umum dibanding kepentingan pribadi.

\section{Keluarga}

Dalam keluarga seseorang harus dididik dan ditanamkan akan nilai-nilai kebersamaan. Melalui musyawarah keluarga, anak membantu orang tua, sikap saling menghormati serta pengajaran tentang arti tanggung jawab dan menumbuhkan kepedulian sosial.

\section{Pemuda}

Pemuda sebagai salah satu agent of change dan merupakan bagian dari masyarakat. Aktivitas para pemuda diharapkan mampu melakukan sebuah perubahan ke arah yang lebih baik. Suara pemuda adalah suara perubahan. Sudah saatnya suara pemuda 
didengungkan kembali setelah kesar terdengar pada reformasi, yang beberapa saat ini jarang terdengar. Pemuda harus kembali menyuarakan perubahan positif untuk kembali pada jati diri bangsa Indonesia seutuhnya.

4. Pemerintah

Pemerintah sebagai penguasa harus mampu mengajak warganya untuk berpartisipasi dalam kegiatan gotong royong. Seminar serta sosialisasi kepada warga akan pentingnya gotong royong perlu dilakukan. Sudah saatnya revolusi mental, seperti yang sedang diusung pemerintahan saat ini untuk lebih menyentuh bagaimana cara mengembalikan jati diri bangsa yang tengah terkikis. Salah satunya adalah dengan menegakkan kembali perilaku gotong royong.

Dengan kontribusi semua pihak untuk menegakkan kembali perilaku gotong - royong demi kembalinya masyarakat pada jati diri bangsanya maka hasil yang akan didapatkan akan semakin massive. Sekaligus memberikan efek yang cepat untuk perubahan yang diinginkan yakni tegakknya jati diri bangsa.

Heider[13] dalam model teori atribusinya menyebutkan perilaku seseorang dapat disimpulkan karena disebabkan oleh kekuatan lingkungan (environmental forces) atau kekuatan internal (diposisi). Kekuatan lingkungan terdiri dari faktor situasi yang menekan, sehingga memunculkan perilaku tertentu. Kekuatan internal (personal forces) dilihat sebagai hasil dari kemampuan (ability), power, dan usaha yang ditunjukkan seseorang.[14][15] Oleh karena itu dalam proses mengembalikan jati diri bangsa dengan menegakkan perilaku gotong royong diperlukan banyak kontributor, tak lain karena pembentuk perilaku, dalam kaitannya perilaku gotong royong, dibutuhkan banyak pula faktor dan kekuatan yang mengerakkan.

\section{E. SIMPULAN DAN SARAN}

Budaya kolektif sebagai jati diri bangsa kini tengah mengalami krisis dan membutuhkan langkah untuk mengembalikan jati diri bangsa pada trek yang benar. Suatu kerugian besar bagi Bangsa Indonesia apabila kehilangan jati dirinya. Hilangnya budaya kolektif sebagai jati diri bangsa tersebut kini sudah banyak terlihat serta ada dalam banyak aspek. Sehingga Cepat atau lambat nilai - nilai asli Indonesia ini akan hilang dan terkikis.

Menegakkan perilaku gotong - royong menjadi salah satu solusi untuk menegakkan kembali jati diri bangsa yang kini tengah luntur. Perilaku gotong royong bukanlah suatu yang asing, karena nilai - nilai dan penerapan gotong - royong sendiri sangat sering diterapkan pada masa lalu sebagai dasar pembangunan Nusantara. Dalam menengakkan kembali perilaku gotong - royong dibutuhkan kontribusi dari banyak pihak. Perilaku bukanlah sesuatu yang mudah untuk diterapkan, namun merupakan konsep yang berimplikasi besar. oleh karena itu dukungan dari semua kontributor pembentuk perilaku mutlak diberikan. Hal itu demi tegakknya perilaku gotong - royong dan kembalinya jati diri bangsa Indonesia yang berasaskan budaya kolektif.

Pada bagian ini penulis merincikan kesimpulan hasil pembahasan dan analisa data dan disarankan untuk menyampaikan penelitian lanjutan untuk peneliti berikutnya.

\section{UCAPAN TERIMA KASIH}

Penulis mengucapkan terima kasih kepada semua pihak yang telah membantu yang senantiasa memberikan bimbingan, nasehat, dan motivasi kepada penulis sehingga penelitian ini selesai dengan baik.

\section{DAFTAR RUJUKAN}

[1] M. A. Mustaqim, "Eksistensi Budaya Gotong Royong (Studi Tentang Makna Perubahan Budaya Gotong Royong Di Desa Kedungsoko Kecamatan Plumpang Kabupaten Tuban Dalam Perspektif Konstruksi Sosial).” UNIVERSITAS AIRLANGGA, 2013.

[2] C. Geertz, Abangan, santri, priyayi: dalam masyarakat Jawa, no. 4. Pustaka Jaya, 1983.

[3] Subagyo, "Pengembangan Nilai dan Tradisi Gotong Royong dalam Bingkai Konservasi Nilai Budaya," Indones. J. Conserv., vol. 1, no. 1, 2012.

[4] M. B. Miles, A. M. Huberman, and J. Saldaña, "Qualitative data analysis: A methods sourcebook. 3rd." Thousand Oaks, CA: Sage, 2014.

[5] A. Marzali, Antropologi \& Pembangunan Indonesia. Prenada Media, 2016.

[6] A. W. Dewantara, "Gotong-royong menurut Soekarno dalam perspektif aksiologi Max Scheler, dan sumbangannya bagi nasionalisme Indonesia." Universitas Gadjah Mada, 2016.

[7] D. Mardiasmo and P. H. Barnes, "Community response to disasters in Indonesia: Gotong Royong; a double edged-sword," in Proceedings of the 9th annual international conference of the international institute for infrastructure renewal and reconstruction, 2015, pp. 301-307.

[8] I. Suprihatin, "Perubahan perilaku bergotong royong masyarakat sekitar perusahaan tambang batu bara di Desa Mulawarman, Kecamatan Tenggarong Seberang," Fak. Ilmu Sos. dan Ilmu Polit. Univ. Mulawarman, Kutai Kartanegara, 2014.

[9] Y. Hanafi, "Model Pendidikan Pesantren Yang Toleran dan Inklusif Berbasis Culture of Peace Education Sebagai Upaya Mengikis Radikalisme Atas Nama Agama,” Dalam J. LP3. Univ. Negeri Malang, 2016.

[10] J. R. Bowen, "On the political construction of tradition: Gotong Royong in Indonesia," J. Asian Stud., pp. 545$561,1986$.

[11] S. Munawaroh, "Pascagempa Intensitas Gotong Royong Semakin Tinggi," Sej. dan Budaya Jawa, p. 1, 2006.

[12] H. J. De Blij, P. O. Muller, and J. Nijman, Geography: realms, regions, and concepts. New YorkWiley, 2014.

[13] S. Azwar, "Sikap Manusia Teori dan Pengukurannya, 
Edisi ke-2," Yogyakarta: Pustaka Pelajar Offset, 2007.

[14] B. S. Pamungkas, "Peranan Pemuda Karang Taruna dalam Kegiatan Gotong Royong Masyarakat (Studi Kasus Masyarakat Desa Kerjo Kidul, Kecamatan Ngadirojo, Kabupaten Wonogiri)," Sos. (Jurnal Ilm. Pend. Sos-Ant), vol. 3, no. 1, 2013.

[15] T. N. Effendi, "Budaya Gotong Royong Masyarakat dalam Perubahan Sosial Saat Ini,” J. Pemikir. Sosiol., vol. 2, no. 1, pp. 1-17, 2013. 